\title{
Nie tylko ISCHEMIA. Sprawozdanie z American Heart Association's Scientific Sessions 2019, Filadelfia 16-18 listopada 2019 roku
}

\author{
Not only ISCHEMIA - report from AHA Scientific Sessions, \\ Philadelphia, 16-18 November, 2019
}

\author{
Tomasz Rechciński (D), Jarosław D. Kasprzak iD \\ I Klinika i Katedra Kardiologii Uniwersytetu Medycznego w Łodzi
}

Od 16 do 18 listopada 2019 roku w Filadelfii (Stany Zjednoczone) odbyły się Scientific Sessions, organizowane przez American Heart Association już od 94 lat. Tegoroczne międzynarodowe spotkanie blisko 15 tys. uczestników zainteresowanych postępem wiedzy o patomechanizmach, diagnozowaniu oraz terapii chorób serca i naczyń krwionośnych jak zawsze było okazją do podsumowania przełomowych wyników badań klinicznych. W 2019 roku były to szczególnie ważne programy badawcze, które z pewnością odcisną swe piętno na kardiologicznej praktyce klinicznej w najbliższych latach.

Środowisko kardiologów (nie tylko interwencyjnych) niecierpliwie oczekiwało ogłoszenia wyników dużego, sponsorowanego przez National Institute of Health badania ISCHEMIA (International Study of Comparative Health Effectiveness With Medical and Invasive Approaches), które dotyczyło poszukiwania właściwej strategii dla pacjentów ze stabilną postacią choroby niedokrwiennej serca oraz udowodnionym podczas testów nieinwazyjnych indukowanym niedokrwieniem miokardium. Nasilenie niedokrwienia było umiarkowane lub duże, co zdefiniowano jedną z czterech metod. Kryteria włączające to: co najmniej 10-procentowy indukowany wysiłkiem ubytek perfuzji w badaniu izotopowym, nie mniej niż 12-procentowe w badaniu metodą rezonansu magnetycznego (MRI, magnetic resonance imaging) lub nowe, obserwowane w czasie obciążenia, zaburzenia kurczliwości w co najmniej 3 z 16 segmentów miokardium ocenianych echokardiograficznie albo w MRI; czwartą alternatywną metodą oceny niedokrwienia była elektrokardiograficzna próba wysiłkowa. Do spełnienia kryteriów włączenia do badania ISCHEMIA wymagano, aby podczas elektrokardiograficznej próby wysiłkowej obniżenia odcinka ST wystąpiły przy obciążeniu mniejszym niż 7 równoważników metabolicznych (MET, metabolic equivalents) lub przed uzyskaniem szczytowej częstotliwości pracy serca poniżej $75 \%$ tętna maksymalnego i miały głębokość co najmniej 1,5 mm w dwóch sąsiednich odprowadzeniach lub co najmniej $2 \mathrm{~mm}$ w dowolnym odprowadzeniu z wyjątkiem odprowadzeń znad strefy przebytego zawału serca. Należy dodać, że obecność spoczynkowych obniżeń odcinka ST wynoszących $1 \mathrm{~mm}$ lub więcej albo obecność bloku lewej odnogi pęczka Hisa, albo cechy przerostu mięśnia lewej komory z zaburzeniami repolaryzacji czy rytm prowadzony przez kardiostymulator były kryteriami wykluczającymi z udziału w programie. Celem badania było rozstrzygnięcie kwestii najwłaściwszego wyboru jednej z dwóch opcji postępowania $w$ tej grupie chorych, tj. optymalnej terapii farmakologicznej albo farmakoterapii poprzedzonej koronarografią i ewentualną rewaskularyzacją zabiegową [1]. Należy podkreślić, że - zważywszy na sprzeczne wyniki mniejszych badań poświęconych tej tematyce - badanie ISCHEMIA zaprojektowano na dużą skalę i ostatecznie włączono do niego 5179 pacjentów, u których przed randomizacją nieznana była anatomia tętnic wieńcowych. U 73\% włączonych pacjentów wykonano jednak tomografię tętnic wieńcowych, by wykluczyć istotne zwężenie pnia lewej tętnicy - obecne u 8,7\% zbadanych; u 13,5\% z tej grupy nie występowały znaczące zwężenia wieńcowe. Trzy czwarte pacjentów zrekrutowano do udziału w tym badaniu na podstawie dodatniego wyniku obrazowego badania obciążeniowego (scyntygrafia, echokardiografia, MRI - w 12\% przypadków wg analizy centralnej nasilenie niedokrwienia przeszacowano), a jedną czwartą - na podstawie silnie dodatniej elektrokardiograficznej próby wysiłkowej. Zdefiniowano

Adres do korespondencji: dr hab. n. med. Tomasz Rechciński, Katedra i Klinika Kardiologii, Uniwersytet Medyczny w Łodzi, Szpital im. Wł. Biegańskiego, ul. Kniaziewicza 1/5, 91-347 Łódź, e-mail: rechcinski@gmail.com 
pięć pierwszorzędowych punktów końcowych: zgon z przyczyn sercowo-naczyniowych, zawał serca, hospitalizacja z powodu niestabilnej dławicy piersiowej, hospitalizacja z powodu niewydolności serca i zresuscytowane zatrzymanie krążenia. Wyniki przedstawiła główna badaczka - Judith Hochman z New York University. Po 5 latach obserwacji nie stwierdzono w badaniu ISCHEMIA znamiennych różnic w liczbie zdarzeń uznanych za pierwszorzędowe punkty końcowe: w grupie zachowawczej ich odsetek wynosił 15\%, a w grupie zabiegowej $13,8 \%$ ( $p=0,34)$. W badaniu wykazano, że u pacjentów z objawowym niedokrwieniem miokardium potwierdzonym w badaniach nieinwazyjnych strategia wykorzystania inwazyjnej koronarografii w wyborze postępowania (u 80\% pacjentów wykonano rewaskularyzację, w tym u 3/4 przezskórną) nie zmienia rokowania w czasie obserwacji trwającej średnio 3,3 roku. Wynik ten stanowi zaskoczenie, szczególnie przy niskim odsetku powikłań rewaskularyzacji. Badanie ISCHEMIA wskazuje też nieoczekiwanie, że powszechnie stosowane nieinwazyjne metody stratyfikacji ryzyka i ukierunkowywania postępowania inwazyjnego nie spełniają oczekiwań i trudno wskazać ich miejsce w rozumowaniu rokowniczym. Co istotne, opisane wyniki nie odnoszą się do pacjentów z niewydolnością serca w III/IV klasie według New York Heart Association (NYHA), z frakcją wyrzutową lewej komory poniżej 35\% oraz nieakceptowalnym nasileniem dławicy, a także ze zwężeniem pnia lewej tętnicy wieńcowej czy po niedawno przebytym ostrym zespole wieńcowym (do 60 dni). Podsumowując badanie ISCHEMIA, Judith Hochman podkreśliła względnie małą śmiertelność pacjentów leczonych w obu grupach tego badania, a ponad wszystko płynący z niego wniosek, że strategia inwazyjna w porównaniu ze strategią zachowawczą nie zapewniała obniżenia ryzyka zdarzeń klinicznych w badanej kohorcie pacjentów - efekt sprowadzał się do silniejszego ograniczenia dławicy u 3 pacjentów na 100 leczonych. Nie zidentyfikowano żadnych kryteriów działających na korzyść którejkolwiek ze strategii, w tym wyodrębnionej w analizie ISCHEMIA-CKD grupie z przewlekłą chorobą nerek.

Kongres dostarczył również interesujących wyników stosowania niekardiologicznych leków w celu obniżenia ryzyka sercowo-naczyniowego - okrzykniętego mianem „outside-the-box approach”, co w polskim tłumaczeniu można ująć jako niekonwencjonalne zastosowanie w kardiologii leków stosowanych we wskazaniach innych niż kardiologiczne.

DAPA-HF (Study to Evaluate the Effect of Dapagliflozin on the Incidence of Worsening Heart Failure or Cardiovascular Death in Patients With Chronic Heart Failure) to program, w którym dowiedziono, że badany w nim lek - dapagliflozyna (inhibitor kotransportera 2 sodowo-glukozowego [SGLT2, sodium-glucose cotransporter 2]) - przynosi podobne korzyści chorym z niewydolnością serca w postaci obniżenia ryzyka sercowo-naczyniowego zarówno u chorych na cukrzyce, jak i u osób bez cukrzycy [2]; tę drugą obserwację przedstawiono w szczegółach w Filadelfii. Badanie, którego wyniki są znane od września 2019 roku, trwało 18 miesięcy i objęło
4744 chorych z niewydolnością serca, w tym $45 \%$ chorych na cukrzycę. Randomizacja polegała na przydzieleniu do grupy otrzymującej $10 \mathrm{mg}$ dapagliflozyny lub placebo niezależnie od rozpoznania cukrzycy. Za pierwszorzędowe punkty końcowe przyjęto zgon, hospitalizacje z powodu niewydolności serca lub stany nagłe związane z niewydolnością serca. Przyjmowanie dapagliflozyny wiązało się z około 26-procentowym zmniejszeniem częstości występowania pierwszorzędowych punktów końcowych nie tylko u chorych na cukrzycę, ale także - co stanowi przełomowe novum - także u pacjentów z niewydolnością serca bez cukrzycy. Porównanie efektów działania dapagliflozyny z placebo między grupą chorych na cukrzyce i pacjentów bez cukrzycy wykazało brak znamiennych różnic w zakresie korzyści odniesionych ze stosowania tego leku: na przykład iloraz szans wystąpienia zgonu z przyczyn sercowo-naczyniowych wynosił w porównywanych grupach odpowiednio 0,79 i 0,85 przy $p=0,7$, a iloraz szans wystąpienia pogorszenia niewydolności serca 0,77 i 0,67 przy $p=0,23$. Ocena zmiany jakości życia o co najmniej 5 punktów za pomocą Kansas City Cardiomyopathy Questionnaire - Total Symptom Score (KCCQ-TSS), zarówno w grupie pacjentów z cukrzycą, jak i bez cukrzycy, wykazała większy odsetek chorych, u których nastąpiła poprawa jakości życia niż tych, u których doszło do jego pogorszenia $-p=0,74$. Profil bezpieczeństwa badanego leku był korzystny, a objawy niepożądane w postaci hipoglikemii lub kwasicy metabolicznej wystąpiły zaledwie u promila pacjentów. Główny badacz programu DAPA-HF, John McMurray z Wielkiej Brytanii, stwierdził w kongresowej relacji, że „klasa leków, do której należy dapagliflozyna, to coś więcej niż leki na cukrzyce; to leki potencjalnie ratujące życie, które zmniejszają odsetek przyjęć do szpitala z powodu niewydolności serca, poprawiają jakość życia w tej grupie chorych, niezależnie od tego, czy rozpoznano u nich cukrzycę lub podwyższone stężenie hemoglobiny glikowanej”. Co ciekawe, żaden z przedstawionych parametrów nasilenia cukrzycy nie zmieniał korzyści z leczenia inhibitorem SGLT2, a siłą ochrony pacjentów bez cukrzycy co najmniej dorównywała wynikom chorych na cukrzycę.

Podobnym do DAPA-HF w skali liczebności badanej grupy chorych był program COLCOT (Colchicine Cardiovascular Outcomes Trial), w którym sprawdzano, w jakim stopniu znany od wielu lat lek przeciwzapalny, stosowany w leczeniu dny moczanowej i w zapaleniu osierdzia - kolchicyna - będzie mógł zmniejszyć liczbę niedokrwiennych zdarzeń sercowo-naczyniowych u osób, które przeżyły zawał serca [3]. Do badania włączano pacjentów w ciągu 30 dni od przebytego zawału serca i losowo przydzielano do grupy przyjmującej 0,5 mg kolchicyny jeden raz dziennie lub placebo, w obu przypadkach jako dodatek do standardowego leczenia po zawale. Pierwszorzędowymi punktami końcowymi w badaniu COLCOT były zgon z przyczyn sercowo-naczyniowych, zresuscytowane nagłe zatrzymanie krążenia, ponowny zawał serca, udar mózgu lub przyjęcie do szpitala z powodu niestabilnej dławicy 
piersiowej wymagającej rewaskularyzacji. Po obserwacji trwającej średnio 23 miesiące w grupie leczonej kolchicyną stwierdzono obniżenie o 23\% ryzyka pierwszego po zawale incydentu naczyniowego i 34-procentowe obniżenie ryzyka wystąpienia zsumowanych zdarzeń sercowo-naczyniowych u pacjentów po niedawno przebytym zawale serca. U większości pacjentów lek był dobrze tolerowany, choć w grupie przyjmującej kolchicynę zauważono niewielki wzrost liczby zapaleń płuc i brak istotnej statystycznie nadwyżki powikłań ze strony przewodu pokarmowego. Jean-Claude Tardif z Centrum Badawczego Montreal Heart Institute, pełniący rolę głównego badacza tego niesponsorowanego przez firmę farmaceutyczną programu, stwierdził, że kardiolodzy zyskują w postaci kolchicyny „podawany doustnie, łatwo dostępny na całym świecie, a do tego niedrogi" farmaceutyk. Kolchicyna, z niedawno zidentyfikowanym mechanizmem działania polegającym na hamowaniu inflamasomów, stała się zatem „cichym bohaterem” kongresu - trudnym do zignorowania w kolejnych wytycznych prewencji wtórnej.

Ważnym wątkiem sesji AHA w Filadelfii były prezentacje wyników terapii innowacyjnymi lekami. Przykładem całkiem nowego podejścia do leczenia hipolipemizujacego jest lek o nazwie inklisiran - krótka cząsteczka kwasu rybonukleinowego interferująca z matrycowym RNA, co powoduje blokowanie transkrypcji białka konwertazy proproteinowej subtilizyny/kexiny 9 (PCSK-9, proprotein convertase subtilisin/kexin type 9) [4], a jej unikalną cechą jest możliwość podawania co pół roku. Efekty podawania inklisiranu u osób ze stabilnym przebiegiem miażdżycowych chorób serca i naczyń oraz stężeniem cholesterolu frakcji LDL (low-density lipoproteins) równym lub przekraczającym $70 \mathrm{mg} / \mathrm{dl}$ testowano w programie ORION-10 (Inclisiran for Participants With Atherosclerotic Cardiovascular Disease and Elevated Low-density Lipoprotein Cholesterol). Punkt końcowy tego programu to stopień obniżenia cholesterolu frakcji LDL w porównaniu z placebo w 510. dniu leczenia oraz odsetek redukcji stężenia cholesterolu frakcji LDL między 90. a 540. dniem leczenia. Iniekcje z badanym lekiem/placebo podawano 1. dnia, następnie po 90 dniach, a potem w odstępach półrocznych. W badaniu ORION-10 z udziałem 1561 pacjentów poddanych randomizacji 1:1 do leczenia aktywnego lub przyjmowania placebo wykazano obniżenie o 58\% stężenia cholesterolu frakcji LDL w 510. dniu badania i 56-procentowe obniżenie tego parametru między 90. a 540. dniem obserwacji. Badanie nie było ukierunkowane na zdarzenia kliniczne, ale ich częstość była nieco niższa w grupie leczonej inklisiranem. Jak powiedział o inklisiranie profesor R. Scott Wright z Mayo Clinic nadzorujący to badanie: jest to „skuteczny, trwale działający i silny” lek. Czyżby pojawił się poważny konkurent dla niedawno wprowadzonych inhibitorów PCSK9?

Mniej spektakularny, lecz godny odnotowania był wynik badania BETonMACE (Effect of RVX000222 on Time to Major Adverse Cardiovascular Events in High-Risk T2DM Subjects With CAD), w którym postanowiono sprawdzić, czy cząsteczka opracowana w celu blokowania epigenetycznych modulatorów transkrypcji (białka BET [bromodomain and extra-terminal domain BRD2, BRD3, BRD4]) związanych z procesem zapalnym, trombogenezą i metabolizmem lipoprotein - apabetalon - będzie zdolna zmniejszyć liczbę zdarzeń naczyniowych u pacjentów leczonych z powodu ostrego zespołu wieńcowego i cukrzycy [5]. W ponad 26-miesięcznej obserwacji 2425 pacjentów poddanych tej innowacyjnej terapii nie wykazano znamiennej statystycznie przewagi (osiągnięte $p=0,11$ ) nowego sposobu zapobiegania nowym incydentom naczyniowym, choć częstość tych zdarzeń w grupie przyjmującej apabetalon (9,5\%) była mniejsza od oczekiwanej (10,5\%). Dobra tolerancja nowego leku oraz mała liczba działań niepożądanych podczas leczenia zachęcają do kontynuacji badań nad „pierwszym lekiem modyfikującym procesy na poziomie epigenetycznym u pacjentów ze schorzeniami sercowo-naczyniowymi na tym bardzo selektywnym szlaku - pozostajemy optymistyczni", jak powiedział profesor Kausik Ray z Imperial College London w Wielkiej Brytanii, główny badacz tego programu.

Powracając od „leków przyszłości” do codziennej praktyki klinicznej, warto zauważyć wyniki programu TWILIGHT-ACS (Ticagrelor With Asplrinor ALoneln HiGH-RiskPatients After Coronary InTerventionfor Acute Coronary Syndrome), w którym pacjentów po przezskórnej interwencji wieńcowej z przyczyn innych niż zawał serca z uniesieniem odcinka ST (STEMI, ST-elevated myocardial infarction) po zakończeniu 3-miesięcznej podwójnej terapii przeciwpłytkowej losowo przydzielano na rok do grupy leczonej tikagrelorem i kwasem acetylosalicylowym albo przyjmującej tikagrelor i placebo [6]. W grupie pacjentów leczonych monoterapią z tikagrelorem w 12-miesięcznej obserwacji - przy porównywalnej częstości zdarzeń naczyniowych - odnotowano zmniejszenie o 53\% powikłań krwotocznych typu 2, 3 lub 5 według klasyfikacji przyjętej przez Bleeding Academic Research Consortium (poza śmiertelnymi krwotokami oznacza to każde krwawienie wymagające interwencji lekarskiej z wyjątkiem krwawienia w ciągu 48 h po chirurgicznej rewaskularyzacji miokardium, sklasyfikowanego jako typ 4, i krwawienia, w przypadku którego pacjent nie szuka pomocy lekarskiej - typ 1), bez sygnału mniejszej skuteczności przeciwzakrzepowej w porównaniu z terapią podwójną. Profesor Usman Baber z Mount Synai Hospital w Nowym Jorku referujący wyniki tego badania podkreślił, że obecnie część pacjentów jest pozbawiana przeciwpłytkowej terapii dwulekowej ze względu na obawy przed groźnym krwawieniem, a wyniki badania TWILIGHT-ACS sugerują, że w tej nowej strategii monoterapia tikagrelorem po ostrym zespole wieńcowym obniża ryzyko krwawienia przy zachowanym efekcie przeciwpłytkowym.

American Heart Association to organizacja stawiająca sobie za cel nie tylko wpływ na edukację specjalistów w dziedzinie kardiologii, lecz także dostrzegająca znaczenie podnoszenia świadomości społecznej w zakresie możliwości wpływu na czynniki ryzyka chorób serca i naczyń. Stąd 
zaprojektowane na szeroką skalę akcje informacyjne, którym w tym roku przyświecał slogan „HEY BIG VAPE, \#QUIT LYING”, czyli „przestańcie kłamać o e-papierosach”. Celem tej akcji jest przełamanie stereotypu myślenia o e-papierosach jako nieszkodliwej dla zdrowia formie używki w świetle licznych doniesień o jednoznacznie chorobotwórczej roli e-papierosów, a także zaangażowanie ustawodawców i agencji regulujących dostęp do tego typu artykułów w walkę o ograniczenie dostępu do e-papierosów dla młodzieży.

$\mathrm{Na}$ zakończenie tego nieco wybiórczego przeglądu wątków ostatnich sesji AHA słowo o polskich akcentach w Filadelfii 2019. Ośrodki z Polski prezentowały 24 doniesienia w formie ustnej lub plakatowej, w sesjach wzięli udział wybrani główni badacze z ISCHEMIA, a w programie Scientific Sessions warto odnotować współorganizację przez Polskie Towarzystwo Kardiologiczne połączonej sesji narodowych towarzystw kardiologicznych zatytułowanej „Global roundtable: arrythmia in unique circumstances", na której przypadek pacjenta z zespołem Brugadów i perspektywy diagnostyki molekularnej w tej jednostce chorobowej zaprezentował dr hab. n. med. Tomasz Rechciński.

\section{Konflikt interesów}

Autorzy deklarują brak konfliktu interesów.

\section{Piśmiennictwo}

1. Hochman JS, Reynolds HR, Bangalore S, et al. ISCHEMIA Research Group. Baseline characteristics and risk profiles of participants in the ISCHEMIA randomized clinical trial. JAMA Cardiol. 2019; 4(3): 273-286, doi: 10.1001/jamacardio.2019.0014, indexed in Pubmed: 30810700 .

2. Kosiborod MN, Jhund PS, Docherty KF, et al. Effects of dapagliflozin on symptoms, function, and quality of life in patients with heart failure and reduced ejection fraction: results from the DAPA-HF trial. Circulation. 2020; 141(2): 90-99, doi: 10.1161/CIRCULATIONAHA.119.044138, indexed in Pubmed: 31736335.

3. Tardif JC, Kouz S, Waters DD, et al. Efficacy and safety of low-dose colchicine after myocardial infarction. N Engl J Med. 2019; 381(26): 2497-2505, doi: 10.1056/NEJMoa1912388, indexed in Pubmed: 31733140.

4. German CA, Shapiro MD. Small interfering RNA therapeutic inclisiran: a new approach to targeting PCSK9. BioDrugs. 2020; 34(1): 1-9, doi: 10.1007/s40259-019-00399-6, indexed in Pubmed: 31782112.

5. Ray KK, Nicholls SJ, Ginsberg HD, et al. Effect of selective BET protein inhibitor apabetalone on cardiovascular outcomes in patients with acute coronary syndrome and diabetes: rationale, design, and baseline characteristics of the BETonMACE trial. Am Heart J. 2019; 217: 72-83, doi: 10.1016/j.ahj.2019.08.001, indexed in Pubmed: 31520897.

6. Mehran R, Cao D, Baber U, et al. Ticagrelor reduces thrombus formation more than clopidogrel, even when co-administered with bivalirudin. Thromb Haemost. 2014; 112(5): 1069-1070, doi: 10.1160/ /TH14-03-0269, indexed in Pubmed: 25104302. 